\title{
Comparing the Negative Emotions, Body Image, Sexual Schemas and Sexual Function in Women with Breast Cancer and Healthy Women
}

\author{
Fateme Sorouri ${ }^{1}$, Hamid Yaghubi ${ }^{2}$ \\ ${ }^{1}$ Faculty of Humanities, Department of Clinical Psychology Shahed University, Tehran, Iran \\ ${ }^{2}$ Shahed University, Tehran, Iran.
}

\begin{abstract}
Aim: The aim of this research was the comparison between negative emotions, body image, sexual schemas and sexual function in women with breast cancer after mastectomy and healthy women. Method: The study included 105 married women diagnosed with breast cancer. After enrolment the participants filled the following questionnaires: Multidimensional Body-Self Relations Questionnaire (MBSRQ), Depression, Anxiety, Stress Scales (DASS-21), Questionnaire of cognitive schema activation in sexual context (QCSASC), Female Sexual Function Index (FSFI). After the two groups were matched in age and education, these questionnaires were administered to the control group of 100 healthy women. Descriptive statistics and t-test were used in data analysis. Results: Results indicate a significant difference between the total score of sexual dysfunction $(p<0.002)$, body image $(p<0.001)$, sexual schema $(p<0.001)$ between the breast cancer group and healthy group. The two groups did not have a significant difference in negative emotions. Conclusion: The results of the current study are similar to the previous studies and can be useful for prevention of mood disorders and sexual dysfunction associated with breast cancer, in order to improve psychological treatment of women with breast cancer.
\end{abstract}

Key words: breast cancer, negative emotions, body image, sexual schemas, sexual function.

Copyright @ 2019 KBCSM, Zagreb

e-mail: alcoholism.kbcsm@gmail.com•www.http://apr.kbcsm.hr

\section{Introduction}

Breast cancer is the uncontrolled division of abnormal cells characterized by the occurrence of malignant tumors in one of the organ structures. It can spread directly or through metastatic dissemination [1]. Breast

\footnotetext{
Correspondence to:

F. Sorouri

E-mail: f_sorouri8@yahoo.com
}

cancer is one of the most common cancers worldwide, affecting 1.67 million people according to the 2012 GLOBOCAN series of the International Agency for Research on Cancer [2]. In Iran, breast cancer is the main cause of cancer morbidity and mortality in women [3]. One out of 8 Iranian women between the age of 45 and 55 is likely to develop breast cancer [4]. Many women experience significant stress after being informed of having the disease, exacerbated by the

\footnotetext{
1 MA in Clinical Psychology, Shahed University, Tehran. Tehran, Persian Gulf highway, Faculty of Humanities, department of Clinical Psychology,: E-mail: f_sorouri8@yahoo.com 
necessary treatments such as surgery and chemotherapy and their side effects [5]. On one hand, the progress of science and the emergence of new treatment options has led to increased life expectancy of many patients. However, psychological disorders caused by the disease and treatment effects persist many years after treatment [6-10].

Sexuality is an important part of human life and has an essential role in the quality of life and health [11]. Sexual dysfunction in women with gynecologic cancer reaches $81 \%$ [13]. Many studies show sexual dysfunction in women with breast cancer [14-19].

Additionally, the results of researches have considered the role of other factors that are also important for the health of women with breast cancer, including negative emotions, body image and sexual schemas [12, 19-21].

One of the important psychological variables in patients with breast cancer are negative emotions. Negative emotions include anxiety, depression and stress. Negative emotions are caused by unpleasant events or experiences. Breast cancer treatments have deep psychological effects on patients due to changes in appearance such as hair loss, mastectomy or breast deformity [22, 23] and cause negative emotions associated with an unpleasant experience [24, 25]. Some researches showed high prevalence of negative emotions in women with breast cancer [7, 2633]. For example, Kissan et al studied women with breast cancer at the Institute of Psychology, University of Melbourne, and estimated the prevalence of major depression at $10 \%$, mild to moderate depression at $27 \%$ and anxiety disorders at 9\% [34].

Most researches have shown that procedures that lead to loss or deformation of a breast have a negative impact on body image of women with breast cancer $[17,18]$.
The body image does not reflect the actual appearance of a person, it is the person's image of the size and shape of her body that includes beliefs, perception, thoughts, feelings and behaviors related to physical appearance [35]. Thompson (1990) points out that the structure of physical appearance includes three components: 1) cognitive factors (estimation of body size), 2) subjective factors (aspects such as satisfaction, attention, anxiety and cognitive assessment) and 3) behavioral components (avoiding situations that cause a person to consider physical appearance as a shameful experience). Previous studies have been implemented in different countries and races on body image in women with breast cancer. Many of these researches indicated a body image disorder [18, 36-40]. In a study on an Iranian sample, the body image between two groups of women with breast cancer, whether undergoing surgery or not, have been examined and no significant relationship existed between them. However these variables were not compared to healthy people [41].

Cognitive schemes, as the core of a person's cognitive structure, assist the person to classify and interpret his or her experiences in meaningful ways [42]. Sexual schemes, as well as other schemes, guide the emotional and behavioral responses to external and internal stimuli with the meaning they give to events. If that does not match the reality, it causes the emotional and behavioral answer that leads to sexual dysfunction. The researches on the association between sexual schemes and sexual function of women with cancer in the United States (2007) showed that people with sexual dysfunction, compared to people with normal function, activate a negative sexual scheme in sexual situations [43].

Due to the high prevalence of breast cancer and the importance of sexual function 
and some psychological variables related to mental health of patients with breast cancer and their families, this study aimed to compare body image, negative emotions, sexual schemas and sexual performance between women with breast cancer and healthy women. In this study, sexual function was compared with the control group as an important aspect of quality of life and one of the commonest psychological disorders in people with this chronic disease [19]. Three other variables may be anticipated in the following researches as factors affecting the person's mental state: disrupting different familial, social and occupational functions as possible causes of sexual dysfunction. In the present study the variable of negative emotions in three categories of anxiety, stress and depression, and body image is studied in comparison with healthy subjects. The previous researches on Iranian samples focus only on patients that are not comparable to healthy subjects due to the lack of a control group. Assessing the variable of sexual schemes in people with breast cancer is a new action in this area. Assessing the dimensions of this issue, without significant support from Iranian research, can be effective for sexual dysfunction in this population and provide a platform for more research in this area or related areas.

\section{Methods}

\section{Participant}

The sample of the study consisted of married women aged 20 to 55 with breast cancer who underwent surgery at least 6 months prior to the study and follow-up cancer treatment in 2013-2014 in medical centers in Zanjan and affiliated centers of Tehran. Purposive sampling was used in selecting the samples. The data were collected as follows: the researcher visited Vali-Asr and Ayatollah Mousavi hospitals of Zanjan (clinics and hospitals of Zanjan University of Medical Sciences), Research Center of Jihad University of Breast Cancer, Cancer Research Center of Shohadaye-Tajrish hospital and Azar Surgery Research Center (cancer-related centers in Tehran) in the first half of 2013 and reviewed women aged 20 to 55 years with breast cancer who had undergone surgery at least 6 months earlier. Eligible patients referred to these treatment centers for followup, willing to participate in the research and meeting the inclusion criteria, were introduced by an oncologist or medical staff to participating in the research. Finally, $120 \mathrm{pa}$ tients were selected and included in the clinical group after signing an informed consent form. From patients' escorts and the hospital health care staff 115 individuals without breast cancer were matched by age and education criteria as the control group. However, due to errors in both groups in completing the questionnaires, ultimately were analyzed 105 in the breast cancer group and 100 in the control group.

The inclusion criteria for the clinical group were: age from 20 to 55 years, being married, history of unilateral or bilateral breast surgery, undergoing surgery at least 6 months prior to the implementation of the study. The inclusion criteria for the control group were: age 20 to 55 years, being married, absence of breast cancer. The exclusion criteria were: age younger than 20 or older than 55 years, being single.

\section{Design of the study}

This study was a part of a cross-sectional proposal. In this design, breast cancer was 
considered as a prediction variable; body image, negative emotions, sexual schemes, and sexual function was considered as a criterion variable.

\section{Study measures}

\section{Multidimensional Body-Self Relations Questionnaire (MBSRQ)}

A 46-item self-report scale was designed by Cash and colleagues in 1987. The final form of the questionnaire prepared in 1997 by Cash was used in this study. This questionnaire had 6 subscales including Appearance Evaluation, Fitness Orientation, Body Areas Satisfaction, Appearance Orientation, Fitness Evaluation and Subjective Weight, to which the participants responded, based on the Likert scale (from strongly disagree $=1$, to strongly agree $=5$ ). Reliability and validity of this test has been validated by Cash [35]. Its psychometric properties have been studied in Iran. Cronbach's alpha coefficients for all subscales are reported, $0.88,0.85,0.83,0.79$, 0.91 and 0.94 , respectively, which is a sign of a good internal consistency of the questionnaire. Correlation coefficients for each subscale within two weeks were $0.78,0.75,0.71$, $0.69,0.84$ and 0.89 , respectively, which is a sign of good test-retest reliability [44].

\section{Female Sexual Function Index (FSFI)}

This tool was designed by Rosen et al in 2002 to assess women's sexual function during the past four weeks [45]. It consists of 19 sexual function verdicts in six independent areas, including desire, arousal, lubrication, orgasm, satisfaction, and pain during sex. Participants responded to this based on the Likert scale (from never or almost never $=$
1.0, to always and almost always $=5$ ). Desire is scored in a subscale of 1 to 5 and the other factors from 0 to 5 (grade 1 and grade 5). In a study by Rosen and colleagues, alpha was 0.89 and in Meston's study 0.74 [46]. Psychometric properties of the Iranian sample were assessed in some studies [47, 48]. According to the latest study conducted by Fakhri and colleagues, the overall stability of the test for each of the above areas ( $\mathrm{r}$ ranging from 0.73 to 0.86$)$ and acceptable internal consistency $(\alpha: 0.72$ to 0.90$)$.

\section{Depression, Anxiety, Stress Scales (DASS-21)}

This questionnaire was developed in 1983 by Lovibond. The scales comprises of 21 items with signs of negative emotions (depression, anxiety and stress). Each of the three measures of depression, anxiety and stress has 7 questions and the participants' score in each of the three subscales is calculated by adding all expressions of that subscale. Several studies have shown that DASS-21 subscales have good psychometric properties. In a non-clinical population, internal consistency coefficients of the three subscales of depression, anxiety and stress were $0.91,0.84$ and 0.90 , respectively 0 [49] and in a study with clinical population were 0.91, 0.89 and 0.93 [50]. Brown and colleagues also reported the test-retest reliability coefficients for three subscales of DASS-21 with an interval of two weeks from 0.71 to 0.81. Three-factored structure of the scale is supported by DASS-21 in various studies [49-51]. Psychometric characteristics of this questionnaire have been validated by an Iranian sample. In this study, using confirmatory factor analysis, the three-factor structure was confirmed. The internal consistency coefficient scales of depression, anxiety and stress 
were $0.87,0.81$ and 0.87 , respectively and coefficients of reliability for the three subscales were $0.84,0.89$, and 0.90 , respectively [ 52 , 53].

\section{Questionnaire of cognitive schema activation in sexual context (QCSASC)}

This questionnaire assesses 28 schemes associated with psychological problems. These schemes have been designed by JS Beck. The test assesses the activation of these schemes in 4 negative positions with the most likely sexual disorders. In test the participants are asked to read four stories. Each person must choose a story that is most similar to their life and specify the most emotional situation (anxiety, disappointment, sadness, fear, guilt, shame, anger, hurt, joy, and satisfaction); then the participants were required to imagine the story that most fit them and rank each of the 28 schemes based on the Likert scale (very false $=1$, very true $=5$ ). The person's score is the total of the 28 items. The higher score indicates more activation of the negative schemes. Cronbach's alpha had a high internal consistency and the test's coefficient was 0.94 , and retest of 0.66 shows good reliability [40]. The questionnaire conducted on samples of men and women addicts in Tehran and its reliability and validity were considered optimal [54].

\section{Methods of data analysis}

For data analysis, in addition to the methods of descriptive statistics, t-test was used for comparison of means and the dimensions of each variable of negative emotions, body image and sexual schemes in both clinical and control groups. These statistical tests were conducted using the computer software SPSS-18.

\section{Results}

The Demographic characteristics presented in Table 1 included age, education level, years of marriage, disease duration, unilateral or bilateral mastectomy in women with breast cancer and healthy women.

Before addressing the main results of the study, it should be noted that the mean score obtained from testing the performance measures showed that the index of sexual function and all its aspects was higher in healthy subjects than in patients and there was a significant difference, based on the t-test, between the total score of the two groups and subscales of "lubrication", "orgasm", "satisfaction", and "pain". This indicates that women with breast cancer have lower sexual function in the mentioned areas. The results presented in Table 2 show that the comparison between women with breast cancer and healthy women was significant in terms of sexual function based on the t-test.

The results presented in Table 3 showed that the mean score of negative emotions included stress, anxiety, depression and the total score was higher in women with breast cancer. T-test showed significant difference in total score and scores of depression, but the difference in stress and anxiety scales were significant at 0.05 between the two groups.

The results presented in Table 3 show that the mean score in all aspects of body image in women with breast cancer was lower than in healthy women. T-test showed a significant difference between the two groups in total score of body image, tending towards appearance, and satisfaction with body parts. 
Table 1. Demographic statistics in women with breast cancer and healthy women

\begin{tabular}{|c|c|c|c|c|}
\hline Demographics & $\begin{array}{l}\text { Breast cancer } \\
(\mathrm{n}=105) \mathrm{n}(\%)\end{array}$ & mean & $\begin{array}{l}\text { Control group } \\
(\mathrm{n}=100) \mathrm{n}(\%)\end{array}$ & mean \\
\hline \multicolumn{5}{|l|}{ Age } \\
\hline $25-34$ & $7(7)$ & \multirow{4}{*}{$41.09(7.9)$} & $6(6)$ & \multirow{4}{*}{$41.5(7.01)$} \\
\hline $35-44$ & $40(38.3)$ & & $30(30)$ & \\
\hline $45-54$ & $45(43.1)$ & & $57(57)$ & \\
\hline $55-65$ & $13(12.5)$ & & $7(7)$ & \\
\hline \multicolumn{5}{|c|}{ Years of marriage } \\
\hline $1-9$ & $7(6.8)$ & \multirow{5}{*}{ 18.45(10.04) } & $10(10)$ & \multirow{5}{*}{$17.9(10.62)$} \\
\hline $10-19$ & $22(20.1)$ & & $17(15)$ & \\
\hline $20-29$ & $34(32.6)$ & & $34(34)$ & \\
\hline $30-39$ & $31(29.7)$ & & $31(31)$ & \\
\hline$>40$ & $6(5.8)$ & & $8(8)$ & \\
\hline \multicolumn{5}{|l|}{ Education level } \\
\hline Under diploma & $42(40)$ & \multirow{6}{*}{-} & $41(41)$ & \multirow{6}{*}{-} \\
\hline Diploma & $35(33.3)$ & & $31(32)$ & \\
\hline Associate & $7(6.7)$ & & $3(3)$ & \\
\hline Bachelor & $19(18.1)$ & & $20(20)$ & \\
\hline Master & $2(1.9)$ & & $4(4)$ & \\
\hline PHD & 0 & & $1(1)$ & \\
\hline \multicolumn{5}{|c|}{ Duration of cancer disease (year) } \\
\hline 1 & $38(36.19)$ & \multirow{6}{*}{$2.30(1.55)$} & \multirow{6}{*}{-} & \multirow{6}{*}{-} \\
\hline 2 & $15(14.28)$ & & & \\
\hline 3 & $16(15.23)$ & & & \\
\hline 4 & $15(14.28)$ & & & \\
\hline 5 & $12(11.42)$ & & & \\
\hline$>5$ & $9(8.57)$ & & & \\
\hline \multicolumn{5}{|l|}{ Mastectomy } \\
\hline $\begin{array}{l}\text { unilateral } \\
\text { bilateral }\end{array}$ & $\begin{array}{c}100(95.2) \\
5(4.76)\end{array}$ & - & - & - \\
\hline
\end{tabular}


Table 2. Comparison of sexual function between women with breast cancer and healthy women

\begin{tabular}{lcccccc}
\hline & $\begin{array}{c}\text { Breast cancer } \\
(\mathrm{N}=105)\end{array}$ & $\begin{array}{c}\text { Control group } \\
(\mathrm{N}=100)\end{array}$ & $\Delta$ & $(95 \% \mathrm{CT})$ & $\mathrm{d}$ & $\mathrm{p}$ \\
\hline Sexual function & & & & & & \\
total score & $15.93(8.9)$ & $20.06(10)$ & -4.13 & $(1.52,6.73)$ & 0.43 & 0.002 \\
Desire & $2.47(1.26)$ & $2.74(1.5)$ & -0.27 & $(-0.11,0.65)$ & 0.22 & 0.175 \\
Arousal & $2.47(1.76)$ & $2.7(1.96)$ & -0.22 & $(-0.28,0.74)$ & 0.12 & 0.394 \\
Lubrication & $2.5(2.05)$ & $3.55(2.44)$ & -1.04 & $(0.43,1.66)$ & 0.46 & 0.001 \\
Orgasm & $2.45(1.93)$ & $3.03(2.19)$ & -.58 & $(0.01,1.14)$ & 0.28 & 0.047 \\
Satisfaction & $3.40(1.73)$ & $4(1.78)$ & -.59 & $(0.11,1.08)$ & 0.34 & 0.019 \\
Pain during sex & $2.65(1.95)$ & $4.12(2.39)$ & -1.47 & $(0.87,2.06)$ & 0.67 & 0.001 \\
\hline
\end{tabular}

Data are presented as mean (standard deviation)

Abbreviation: $\Delta=$ mean difference; $\mathrm{d}=$ cohen's d standardized effect size; $\mathrm{CI}=$ confidence interval; $\mathrm{p}=$ statiscal significance calculated using students t-test for independent samples

Table 3. Comparison of negative emotions between the group of women with breast cancer and healthy women

\begin{tabular}{lcccccc}
\hline $\begin{array}{l}\text { Dimensions of } \\
\text { negative emotions }\end{array}$ & $\begin{array}{c}\text { Breast cancer } \\
(\mathrm{N}=105)\end{array}$ & $\begin{array}{c}\text { Control group } \\
(\mathrm{N}=100)\end{array}$ & $\Delta$ & $(95 \% \mathrm{CT})$ & $\mathrm{d}$ & $\mathrm{p}$ \\
\hline Total score & $40.51(27.87)$ & $33.31(26.50)$ & 7.19 & $(-0.29,14.69)$ & 0.26 & 0.064 \\
Stress & $16.21(10.56)$ & $13.17(9.95)$ & 3.041 & $(0.21,5.86)$ & 0.29 & 0.039 \\
Anxiety & $12.55(9.37)$ & $9.76(8.71)$ & 2.78 & $(0.29,5.28)$ & 0.3 & 0.032 \\
Depression & $12.01(10.54)$ & $10.38(10.02)$ & 1.63 & $(-1.20,4.46)$ & 0.15 & 0.266 \\
\hline
\end{tabular}

Data are presented as mean (standard deviation)

Abbreviation: $\Delta=$ mean difference; $\mathrm{d}=$ cohen's d standardized effect size; $\mathrm{CI}=$ confidence interval; $\mathrm{p}=$ statiscal significance calculated using students t-test for independent samples

Table 4. Comparison of body image between the group of women with breast cancer and healthy women

\begin{tabular}{lcccccc}
\hline $\begin{array}{l}\text { Dimensions of body } \\
\text { image }\end{array}$ & $\begin{array}{c}\text { Breast cancer } \\
(\mathrm{N}=105)\end{array}$ & $\begin{array}{c}\text { Control group } \\
\mathrm{N}=100)\end{array}$ & $\Delta$ & $(95 \% \mathrm{CT})$ & $\mathrm{d}$ & $\mathrm{p}$ \\
\hline Total score & $150.56(15.44)$ & $158.78(12.45)$ & -8.22 & $(3.20,13.41)$ & 0.58 & 0.001 \\
Appearance & $22.02(3.81)$ & $22.58(4.05)$ & 0.56 & $(-0.86,1.98)$ & 0.14 & 0.318 \\
Evaluation & & & & & & \\
Appearance & & & & & & \\
Orientation & $39.1(15.71)$ & $42.86(5.41)$ & -3.74 & $(-0.54,8.06)$ & 0.32 & 0.001 \\
Fitness Evaluation & $9.68(2.31)$ & $10.16(1.83)$ & -0.48 & $(-0.27,1.23)$ & 0.23 & 0.101 \\
Fitness Orientation & $39.95(6.41)$ & $39.03(5.49)$ & 0.92 & $(-1.25,3.09)$ & 0.15 & 0.281 \\
Subjective Weight & $7.18(1.56)$ & $7.37(1.57)$ & -0.19 & $(-0.37,0.75)$ & 0.12 & 0.379 \\
Body Areas & & & & & & \\
Satisfaction & $32.92(7.51)$ & $36.75(5.35)$ & -3.83 & $(1.45,6.20)$ & 0.58 & 0.001 \\
\hline
\end{tabular}

Data are presented as mean (standard deviation).

Abbreviation: $\Delta=$ mean difference; $\mathrm{d}=$ cohen's d standardized effect size; $\mathrm{CI}=$ confidence interval; $\mathrm{p}=$ statiscal significance calculated using students t-test for independent samples 
Table 5. Comparison between women with breast cancer and healthy women in subscales of negative sexual schemas

\begin{tabular}{lcccccc}
\hline $\begin{array}{l}\text { Dimensions of sexual } \\
\text { schemas }\end{array}$ & $\begin{array}{c}\text { Breast cancer } \\
(\mathrm{N}=105)\end{array}$ & $\begin{array}{c}\text { Control group } \\
(\mathrm{N}=100)\end{array}$ & $\Delta$ & $(95 \% \mathrm{CT})$ & $\mathrm{d}$ & $\mathrm{p}$ \\
\hline $\begin{array}{l}\text { (Total score) } \\
\text { Undesirability/ }\end{array}$ & $53.93(20.89)$ & 40.3719 .57 & 13.56 & $(6.2,20.92)$ & 0.13 & 0.001 \\
Rejection & $15.44(7.42)$ & 12.488 .43 & 2.95 & $(0.079,5.84)$ & 0.02 & 0.009 \\
Incompetence & $16.97(7.44)$ & 12.286 .14 & 4.68 & $(2.20,7.17)$ & 0.04 & 0.001 \\
Self-depreciation & $4.85(2.49)$ & 4.112 .10 & 0.74 & $(-0.1,1.58)$ & 0.007 & 0.026 \\
Difference and & $7.23(2.88)$ & 4.672 .62 & 2.56 & $(1.55,3.56)$ & 0.02 & 0.001 \\
loneliness & $9.41(4.33)$ & 6.804 .06 & 2.61 & $(1.08,4.13)$ & 0.02 & 0.001 \\
Hopeless & & & & & &
\end{tabular}

Data are presented as mean (standard deviation)

Abbreviation: $\Delta$ = mean difference; $\mathrm{d}=$ cohen's d standardized effect size; $\mathrm{CI}=$ confidence interval; $\mathrm{p}=$ statiscal significance calculated using students t-test for independent samples

T-test showed no significant difference in the evaluation of other scales.

The results presented in Table 5 showed that the mean score of negative sexual scheme was higher in all aspects in women with breast cancer than in healthy women. Ttest showed no significant difference between the total score of the two groups. Thus, it was confirmed that women with breast cancer have a more negative sexual scheme than healthy women.

\section{Discussion and conclusion}

The aim of this study was to compare the variables of negative emotions, body image, sexual schemes and sexual function in women with breast cancer and healthy women. Before discussing the main results, it must be mentioned that the clinical and control groups were matched in terms of age and education. The results showed that breast cancer patients had lower scores in all aspects of sexual function than the healthy controls. This difference was significant in the subscales of "lubrication", "orgasm", "satisfaction" and "pain". Negative emotions (stress, anxiety and depression) were higher in patients with cancer than in normal individuals, but there was no significant difference between the total score of negative emotions. Scores of women with breast cancer in the two subscales of body image, including towards appearance and satisfaction with body parts, were lower than in the control group and the difference was significant. Also, women with cancer had a significant difference in negative sexual schemes from the control group.

The results of studying the negative emotions in women with breast cancer are in line with the results of the following researchers: Kissan et al [36], Morasso et al [28], Jesse et al [29], Khan et al [30], Alacacioglu et al [31], and Alavi and Monaie [7]. The higher mean score of negative emotions (stress, anxiety and depression) in the group of patients than the control group explained that women with breast cancer become closer to 
the issues associated with psychopathology. Women who undergo surgery experience significant stress and tension due to the disruption of their body image. Thus, they may use emotion-focused coping mechanisms [55] that may cause high levels of anxiety and depression [56]. Higher scores of negative emotions in women with cancer and, at the same time, no significant relationship between the scores of the two groups, indicate the importance of assessing the details of the negative emotions and psychological, social and family infrastructure in both groups.

The results of the body image are also consistent with findings of previous researchers, including researches by Fobair et al [18], Barni [38], Bakht and Najafi [42] and Harirchi et al [16]. In explaining the problems related to body image and sexual function, the findings of Fabiar et al [18] pointed out that most of the problems in patients with breast cancer are associated with chemotherapyinduced factors such as hair loss, increased concerns of weight gain or weight loss, impaired mental health, low self-esteem and low understanding of the patient's sexual partner. This explanation is in line with researches by Boquiren et al [19], Male et al [40].

The results of this study regarding the negative sexual scheme in the clinical group is consistent with the researches by Nobre and Pinto-Gouveia [44] on the incidence and types of negative sexual schemes in the affected female patients. There was a significant difference between healthy women and women with breast cancer in all subscales of negative sexual schemas Undesirability/ rejection, Incompetence, Self-depreciation, Difference/loneliness, and Helplessness.

The relationship between sexual schemes and sexual function is one of the areas that has been considered only recently and previously less studied. Women with cancer show more negative sexual schema due to the presence of disease and secondary sexual dysfunction. Due to the illness, parts of the sexual function is impaired, such as lubrication and sex drive, which are affected by cancer treatments such as radiotherapy, chemotherapy and prevention drugs. Thus, it seems that the person does not control these physiological changes, so she experiences loss of control, helplessness and inadequacy. The results of Nobre and Pinto-Gouveia [44] have also confirmed this.

One of the limitations of this study was not including the individual's stressors and mental state in the family before the disease onset and neglecting the role of the patient's spouse and the communication patterns as the main factor in the patient's sex life. Thus, this study was based on purposive sampling with a higher risk of sampling bias. It is recommended that future studies consider the role of the patient's spouse and the role of psychosocial stressors on sexual function.

The results of this study provide useful information to clinical psychologists, physicians and researchers in the context of negative emotions, body image, sexual schemes and sexual function in breast cancer patients that can be used and cited in different areas of research, prevention and treatment. It is an effective step towards improving the quality of psychological treatment and prevention of mood disorders and sexual function in breast cancer patients and improving their quality of life.

\section{Acknowledgements}

Professor Akbari, Head of Cancer Research Center of Shahid Beheshti Univer- 
sity of Medical Science, the respected personnel of Azar Surgery Center, especially Ms. Khorsand, and Ms. Sheikhi, the President of the Breast Cancer Research Institute (SID) are appreciated for providing sincere

\section{References}

1. Peres RS, Santos MA. Breast cancer, poverty and mental health: Emotional response to the disease in women from popular classes. Revista Latinoamericana de Enfermagem. 2007; 15:787-788.

2. Ferlay J, Soerjomataram I, Dikshit R, Eser S, Mathers C, Rebelo M, Bray F. Cancer incidence and mortality worldwide: Sources, methods and major patterns in GLOBOCAN 2012. International Journal of Cancer. 2014;136:359-386.

3. Asadzadeh Vostakolaei F, Broeders MJ, Mousavi SM, Kiemeney LA, Verbeek AL. The effect of demographic and lifestyle changes on the burden of breast cancer in Iranian women: A projection to 2030. The Breast. 2013; 22: 277-281.

4. Taleghani F, Parsa Yekta Z, Nikbakht Nasrabidi A. Coping with breast cancer in newly diagnosed Iranian women. J O Advanced Nursing. 2006;54: 265 273.

5. Mokhtari L, Rezaei M, Pour principle M, Mohsen Mousavi S. Health beliefs of women health workers to carry out self-examination and clinical breast examination. Health and care. 1989;10:115-123.

6. Pedram M, Mohammadi M, Naziri GH, Aeinparast $\mathrm{N}$. The effectiveness of cognitive behavioral group therapy in the treatment of anxiety, depression disorder and hope creation for women with breast cancer. Woman quarterly of scientific research. 2010;7:233-245.

7. Alavi NS, Monaei M. Anxiety in cancer patients and dealing with it. Iran Quarterly of breast disease. 2009;2:43-45.

8. Porter LS, Clayton MF, Belyea M. Predicting negative mood state and personal growth in African American and White long-term breast cancer survivors. Ann Behav Med. 2006; 31:195-204. cooperation in the implementation of the research.

\section{Conflict of interest}

None to declare.
9. Deshields T, Tibbs T, Fan MY, Taylor M. Differences in patterns of depression after treatment for breast cancer. Psycho oncology. 2006;15:398-406.

10. Hayati F, Shahsavari A, Mahmodi M. Relation psychic convenience with individual factors of patients with breast cancer in hospitals of Tehran University of Medical Science. Journal of Iran breast diseases.2009;2:23-28.

11. Naziri GH, Ghaderi Z, Zare F. The effectiveness of narrative therapy on decreasing depression in women of marvdasht city. Women sociology (woman and society). 2009;1:65-78.

12. Sadock BJ, Kaplan HI, Sadock VA. Kaplan and Sadock s synopsis of psychiatry. Philadelphia: USA Lippincott Williams \& Wilkins. 2007.

13. Anderson JL. Acknowledging Female Sexual Dysfunction in Women with Cancer. Clin J Oncol Nurs. 2013;17:233-5.

14. Bakewell RT, Volker Dl. Sexual dysfunction related to the treatment of young women with breast cancer. Oncology journal. 2006;6: 697-702.

15. Sbitti Y, Kadiri I, Fadoukhair Z, Kharmoun S, Slimani KH. Breast cancer treatment and sexual dysfunction: Moroccan women's perception. Women's health. 2011;1:45-60.

16. Harirchi A, Montazeri A, Zamani Bidokhti F, Mamishi N, Zendeh K. Sexual function in breast cancer patients: a prospective study from Iran. Journal of Experimental \& Clinical Cancer Research. 2012;31:31-36.

17. O”nen Serto Z, Elbi Mete H, Noyan A. Effect of surgery type on sexuality, body image, self-esteem and marital adjustment in breast cancer: a controlled trial. J Psychosom Res. 2003; 55: 147-178

18. Fobair P, Stewart SL, Chang S, D’Onofrio C, Banks PJ, Bloom JR. Body image and sexual problems in 
young women with breast cancer. Psycho oncology. 2006;15:79-94.

19. Boquiren VM , Esplen MJ ,Wong J ,Toner, B , Warner E, Malik N. Sexual functioning in breast cancer survivors experiencing body image disturbance. Psycho-Oncology. 2006;25:66-76.

20. Reich M, Lesur A, Perdrizet- Chevallier C. Depression, quality of life and breast cancer: a review of the literature. Breast Cancer Research and Treatment. 2008;110:9-17.

21. Male DA., Fergus KD, Cullen K. Sexual identity after breast cancer. Current Opinion in Supportive and Palliative Care. 2016;10:66-74.

22. Ghasami M. Psychometric assessment of sexual function scale (FSFI) and the revised form of Female Sexual Distress (FSDF) [dissertation].[Tehran]: Shahed University; 2009. 120 p.

23. Soltaninejad Z. Sexual relationship with aspects of personality and body image in pregnant women and non-pregnant [dissertation].[Tehran]: Shahed University; 2008. 102 p.

24. Frith Harcourt D, Fussell A. Anticipating an altered appearance: women undergoing chemotherapy treatment for breast cancer. European journal of oncology nursing. 2007;11: 385-391.

25. Moreira H, Silva S, Margues A, Canavarro MC. The Portuguese version of the body image scale (BIS) - psychometric properties in sample of breast cancer patients. European journal of oncology nursing. 2007;14: 111-118.

26. Sepah, SC, Bower JE. Positive affect and inflammation during radiation treatment for breast and prostate cancer. Brain, Behavior and Immunity. 2009;23:1068-1072.

27. Kernan WD, Lepore SJ. Searching for meaning making after breast cancer: prevalence, pattern and negative affect. Social Science and Medicine. 2009; 68:1176-1182.

28. Morasso G, Costantini M, Viterbori P, Bonci F, Mastro L. Predicting mood disorders in breast cancer patients. European Journal of Cancer. 2001;37:216-223.

29. Jesse R, Fann MD, Anne M, Thomas-Rich D, Wayne J, Katon M. Major depression after breast cancer: a review of epidemiology and treatment. Hospital Psychiatry. 2008;30:112-126.

30. Khan F, Amatya B, Pallant J, Rajapaksa I. Factors associated with long-term functional outcomes and psychological sequel in women after breast cancer. The Breast. 2012; 21:314-20.

31. Alacacioglu A, Yavuzsen T, Dirioz M, Yilmaz U, Snoj Z, Licina M, Pregelj P. Depression and anxiety in Slovenian female cancer patients. Psychiatr Danub. 2008;20:157-161.

32. Mehnert A, Berg P, Henrich G, Herschbach P. Fear of cancer progression and cancer related intrusive cognitions in breast cancer. Oncol surgery. 2003;8:13.

33. Montazeri A. Anxiety and depression in women referring to mammography clinic. Jihad daneshgahi of Tehran medical university. 2004;9:24-30.

34. Fann JR, Thomas-Rich AM, Katon WJ. Major depression after breast cancer: a review of epidemiology and treatment. General Hospital Psychiatry. 2008;30:112-26.

35. Burgess C, Cornelius V, Love S, Graham J, Richards M, Ramirez A. Depression and anxiety in women with early breast cancer: five year observational cohort study. BMJ. 2005;330:702 -5.

36. Kissan DW, Bloch S, Simth GC, Miach P. Cognitive -existential group psychotherapy for women with primary breast cancer. Psycho oncology. 2003;6: 46-532.

37. Cash TF. The Body Image Work Book: an 8-step program for learning to like your looks. New Harbinger publications 1997;5: 45-87.

38. Barni S, Mondin L. Sexual dysfunction in treated breast cancer patient. Sexual dysfunction. 1997; 2:5-149.

39. Schover LR, Montage DK, Lakin MM. Sexual problem in cancer: principle and practice of oncology. 1997;285-287.

40. Takahashi M, Kai I. Sexuality after breast cancer treatment: changes and coping strategies among Japanese survivors. Social Science \& Medicine. 2005;61:1278-1290.

41. Laumann EO, Paik A, Rosen RC. Sexual dysfunction in the United States: prevalence and predictors. JAMA. 1999;281:37-44.

42. Bakht S, Najafi S. Body image and sexual dysfunctions: comparison between breast cancer patients and healthy women. Procedia Social and Behavioral Sciences. 2010;5:1493-97.

43. Sadeghi Someh Olyayi R, Khodabakhshi Kolayi A, Akbari ME, Kohsariyan M, Kalhornia M. Body image and self-esteem: The comparison between 
two group of women with breast cancer(in Persian).Iranian journal of breast diseases. 2012; 5:1629.

44. Nobre, P. J., Pinto-Gouveia, J. Questionnaire of Cognitive Schema Activation in Sexual Context (QCASC). The journal of sex research. 2009; 46:113.

45. Carpenter MK, Andersen BL, Fowler JM, Maxwe GL. Sexual self schema as a moderator of sexual and psychological outcomes for gynecologic cancer survivors. Arch Sex Behav. 2008; 38:828-841.

46. Rahati A. Assessment of body image development and its relationship with self-esteem by comparing age groups; teenagers, middle-aged and elderly dysfunction. Review of validated methods. Fertility and Sterility. 2002;77:80-93.

47. Meston M. Validation of Female Sexual Function Index (FSFI) in the women with female orgasmic disorder and in women with hypoactive sexual desire disorder. Journal of Sex and Marital Therapy. 2003;29:39-49.

48. Mohammadi KH, Heidari M,Faghihzadeh S. Validity of the Persian version of the female sexual function index. Payesh Quarterly. 2008;7:269-278.

49. Lovibond SH, Lovibond PF. Manual for the depression anxiety Stress scales. Psychology Foundation. 1995; 7:23-98.

50. Brown TA, Chorpita BE, Korotitsch W, Barlow D H. Psychometric properties of the Depression
Anxiety Stress Scales (DASS) in clinical samples. Behavior Research and Therapy. 1997;35:79-89.

51. Antony M, Bieling PJ, Cox BJ, Enns MW, Swinson RP. Psychometric properties of the 42-item and 21-item versions of the depression anxiety and stress scales in clinical groups and community sample. Psychological Assessment. 1998;10:179181.

52. Asghari moghadam MA, Mehrabian N, Paknejad M, Saed F. Psychometric properties of the scales of depression, anxiety and stress in pain patients. Journal of Psychology and Education, Tehran University. 2010; 1:13-20

53. Asghari Moghadam MA, Saed F, Dibaj Nia P, Zanganeh J. A preliminary validity and reliability study of depression, anxiety and stress scales (DASS) in non-clinical samples. Daneshvar magazine. 2008;15:22-30.

54. Rostami R. The prevalence of sexual dysfunction and cognitive variables associated with it in male opiates addicts in Tehran. The second Congress of Clinical Psychology Research. Tehran. 2008.

55. Maguire GP. Psychiatric problems in the first year after mastectomy. Br Med. 1978;1:16-23.

56. Austenfeld JL, Stanton AL. Coping through emotional approach: A new look at emotion, coping and health-related outcome. J Pers. 2004;72:35-64.

\section{Usporedba negativnih emocija, slike o tijelu, spolnih shema i seksualne funkcije u žena $s$ rakom dojke i zdravih žena}

Sažetak - Cilj istraživanja je usporedba negativnih emocija, slike o tijelu, spolnih shema i seksualne funkcije žena s rakom dojke nakon mastektomije i zdravih žena. Za istraživanje je odabrano 105 udanih žena s rakom dojke. Nakon odabira kandidatkinje su ispunile sljedeće upitnike: multidimenzionalni upitnik o korelatima zadovoljstva tijelom (MBSRQ), skale za depresiju, anksioznost, stres (DASS-21), upitnik o aktivaciji kognitivnih shema u seksualnom kontekstu (QCSASC) i indeks ženske seksualne funkcije (FSFI). U skladu s dobi i obrazovanjem ispitanica, upitnici su podijeljeni kontrolnoj skupini od 100 zdravih žena; podaci su analizirani pomoću deskriptivne statistike i t-testa. Rezultati ukazuju na značajnu razliku u ukupnom rezultatu seksualne disfunkcije $(p<0 / 002)$, slike o tjelu $(p<0 / 001)$, spolnoj shemi $(p<0 / 001)$ između zdrave skupine i skupine s rakom. Između skupina nije otkrivena značajna razlika u negativnim osjećajima. Rezultat ovog istraživanja sličan je onima iz prethodnih istraživanja te može biti koristan u daljnjem istraživanju prevencije i liječenja raka dojke u svrhu poboljšanja kvalitete psihološke pomoći u liječenju žena s rakom dojke.

Ključne riječi: rak dojke, negativne emocije, slika o tijelu, spolne sheme, seksualna funkcija. 